\title{
ESTIMATION OF SECONDARY PRODUCTION OF THE FARO/ANCÃO ARTIFICIAL REEFS*
}

\author{
Ana Moura ${ }^{1}$, Luis Cancela da Fonseca ${ }^{2}$, Diana Boaventura ${ }^{3,4}$, \\ Miguel Neves Santos ${ }^{1} * *$ and Carlos Costa Monteiro ${ }^{1}$ \\ ${ }^{1}$ Instituto Nacional de Recursos Biológicos (INRB I.P./IPIMAR) \\ (Av. 5 de Outubro s/n, 8700-305 Olhão, Portugal) \\ ${ }^{2}$ Faculdade de Ciência e Tecnologia, Universidade do Algarve \\ (Campus de Gambelas, 8005-139 Faro, Portugal) \\ ${ }^{3}$ Laboratório Marítimo da Guia/Centro de Oceanografia (FCUL) \\ (Av. N. Sra. do Cabo, 939, 2750-374 Cascais, Portugal) \\ ${ }^{4}$ Escola Superior de Educação "João de Deus" \\ (Av. Álvares Cabral, 69, 1269-094, Lisboa, Portugal) \\ **Corresponding author: mnsantos@ipimar.pt
}

\section{A B S TR ACT}

The secondary productivity of reef epifauna is one of the least investigated aspects in artificial reef research. During the first 12 months after the deployment of the Faro/Ancão (Algarve, Portugal) artificial reef, we assessed the effect of substratum orientation on the secondary production of epibenthos, using the Boysen-Jensen method. Whenever the method could not be applied, secondary production was estimated by the $\mathrm{P} / \mathrm{B}$ ratio. The results showed that the epibenthic production was higher on the horizontal surface throughout the study. However, at the end of the study period, the mean production showed similar values. The horizontally oriented surfaces showed a mean production between 128 and $103 \mathrm{~g} \mathrm{~m}-2 \mathrm{yr}-1$, while at the vertical surfaces the mean production varied between 103 and $98 \mathrm{~g} \mathrm{~m}-2 \mathrm{yr}-1$. Furthermore, the mean annual production was extrapolated for all the Algarve artificial reef complex,and we concluded that after one year of deployment theses artificial reefs were able to generate around 5 MT of epibenthic fauna.

\section{RESUMO}

Um dos aspectos menos estudados sobre o funcionamento dos recifes artificiais prende-se com a sua produção secundária. Nesse sentido, ao longo dos primeiros 12 meses após a implantação do recife artificial de Faro/Ancão (Algarve, Portugal), desenvolveu-se um estudo com o objectivo de avaliar o efeito da orientação do substrato na produção secundária de epibentos, usando o método de BoysenJensen. Nos casos em que não foi possível aplicar este método, a produção secundária foi estimada a partir da taxa P/B. Os resultados mostraram que a produção epibêntica foi mais elevada na superfície horizontal. No entanto, no final do período de estudo, a produção média apresentou valores semelhantes. As superfícies de orientação horizontal tiveram uma produção média entre 128 e $103 \mathrm{~g}$ $\mathrm{m}-2 \mathrm{yr}-1$, enquanto as superfícies verticais apresentaram uma produção média entre 103 e $98 \mathrm{~g} \mathrm{~m}$ 2 yr-1. A partir destes valores extrapolou-se a produção média anual para o complexo recifal da costa algarvia, tendo-se concluído que após um ano de implantação este complexo recifal gera cerca de 5 toneladas de fauna epibêntica.

Descriptors: Secondary production, Artificial reefs, Algarve (Portugal).

Descritores: Produção secundária, Recifes artificiais, Algarve (Portugal).

(*) Paper presented at the $9^{\text {th }}$ CARAH - International Conference on Artificial Reefs and Related Aquatic Habitats on 8-13 November, Curitiba, PR, Brazil. 


\section{INTRODUCTION}

In spite of the growing use of reefs for restoration and mitigation, only a few studies have provided substantive guidance on quantifying the necessary amount of structure to ensure adequate habitat replacement. Bohnsack and Sutherland (1985) have referred to the need of artificial reef (AR) productivity estimates to assess habitat restoration or mitigation success. Secondary production is a measurement of biological material created over a specific unit of time. This value is useful in comparing different habitats inhabited by a variety of species with different life histories and growth rates (BURTON et al., 2002). Despite their importance, few productivity studies have been undertaken and these have considered mostly fish (JOHNSON et al., 1994; WILSON et al., 2001). Traditional methods for calculating the secondary production of the benthos have been applied to single animals or populations based on their change in body mass or growth over time. Generally, methods include those based on cohort analysis, size class based methods and the relationship between productivity and mortality (MORIN et al., 1987). None of these methods is feasible when trying to quantify secondary production at the community level. In this case, biomass data were used to estimate the secondary productivity of epifauna that colonised ARs. Concrete reef units were deployed on the southern coast of the Algarve to mitigate the scarcity of natural reefs and to enhance local fisheries. The development of the reef's epibenthic community, and its use as prey, has been reported (LEITÃO et al., 2007; MOURA et al., 2008). In this study, the assessment of the effect of surface orientation in the secondary production of the epifaunal benthos on two ARs of the Faro/Ancão AR system was undertaken over a one-year period.

\section{Material and Methods}

This AR system was spread over an area of $12.2 \mathrm{~km}^{2}$ off Faro (Algarve, southern Portugal), on a sandy bottom. This study was performed on two randomly selected AR groups submerged in August 2002 at $20 \mathrm{~m}$ depth. Each AR group comprises three reef sets of 35 modules each (each module being of $2.7 \mathrm{~m}^{3}$ ) (see MOURA et al., 2008 for more information on these systems). The study of macrobenthic colonisation was performed using cubic sample units $(15 \mathrm{~cm}$ side length) made of the same concrete material as the reef modules. The cubic sample units were set randomly when the reef was immersed. During the first year of immersion, three replicate samples were retrieved from each reef group at six and twelve months by scuba divers. In the laboratory, three out of the six cube surfaces (vertical: inside and outside; horizontal: top) were compared to investigate the role of surface orientation in benthic secondary production. Prior studies have concluded that no differences in abundance, biomass and number of taxa were to be observed as between inside and outside surfaces (MOURA et al., 2004; MOURA et al., 2008), for the present study, both surfaces were analysed together as vertical surfaces. The samples were sieved through a $0.5 \mathrm{~mm}$ square mesh and the material retained was fixed in $4 \%$ buffered formalin. The biomass was obtained for biological samples dried to a constant weight at $70^{\circ} \mathrm{C}$ (usually for at least $24-48$ h). The ash-free dry weight (AFDW) was determined by burning the animals at $450^{\circ} \mathrm{C}$ for $4 \mathrm{~h}$ in a muffle furnace. The AFDW was calculated by subtracting the ash weight from the dry weight.

\section{Data Analysis}

The estimated production rates of the substrata with different orientation were calculated using the method of Boysen-Jensen (YABLONSKAYA; BEKMAN; WINDBERG, 1971). The growth increment is obtained from the sum of consumption and the biomass remaining, after subtracting the initial biomass Eq. (1):

$\mathrm{P}=\mathrm{B}_{\mathrm{e}}+\mathrm{B}_{2}-\mathrm{B}_{1}$

the magnitude of consumption $\left(B_{e}\right)$ was taken to be the difference between the initial $\left(N_{l}\right)$ and final $\left(N_{2}\right)$ numbers, multiplied by the arithmetical mean of the initial $\left(B_{1} / N_{1}\right)$ and the final $\left(B_{2} / N_{2}\right)$ mean individual weights of the groups of animals under consideration. Thus $B_{e}$ is given by the equation Eq. (2):

$\mathrm{B}_{\mathrm{e}}=\left(\mathrm{N}_{1}-\mathrm{N}_{2}\right) \times 1 / 2 \times\left(\mathrm{B}_{1} / \mathrm{N}_{1}+\mathrm{B}_{2} / \mathrm{N}_{2}\right)$

For some epifaunal species, biomass data were available, but abundance data were not. This occurred either because the animals were colonial (thus it was not possible to count the number of individuals) or strongly bonded to the concrete surface (such as barnacles). In these cases it was not possible to account for production directly by applying the Boysen-Jensen method. Secondary production was estimated by the $\mathrm{P} / \mathrm{B}$ ratio (of 0.012) provided by Brey (2002) for miscellaneous benthic invertebrates.

\section{RESUlts}

As expected, the estimated mean production increased after the AR deployment (Fig. 1). All surfaces showed a similar pattern, with a strong 
increase after six months. After six months, the horizontally oriented surfaces exhibited a $10 \%$ higher production than the vertically oriented ones. The horizontally oriented surfaces had a mean production of $128 \mathrm{~g} \mathrm{~m}^{-2} \mathrm{yr}^{-1}$, while the vertically oriented surfaces showed a mean production of $103 \mathrm{~g} \mathrm{~m}^{-2} \mathrm{yr}^{-1}$. However, one year after deployment, the mean production of the surfaces of both orientations presented a slow increment, showing similar values. Still, the horizontally oriented surfaces exhibited an epibenthic production $10 \%$ greater $\left(103 \mathrm{~g} \mathrm{~m}^{-2} \mathrm{yr}^{-1}\right)$ than did the vertically oriented ones $\left(98 \mathrm{~g} \mathrm{~m}^{-2} \mathrm{yr}^{-1}\right)$.

The mean annual production for the whole Algarve AR complex was estimated by extrapolation from these data. This complex comprises approximately $81 \%$ of vertical and $19 \%$ of horizontal surfaces. After one year of deployment, the entire AR complex of the Algarve (with a 10ha surface area available for epibentic colonisation) will then have produced 10 tons. On average, 8 tons will be produced on 8 ha of vertical surfaces and 2 tons on 2 ha of horizontal surfaces.

\section{Discussion}

ARs have the potential to fulfil the many objectives for which they are promoted. However, their success will ultimately reflect the quality of prior planning and management (BAINE, 2001). The Algarve AR complex's construction required the development of a set of design parameters that should guarantee a persistent structural stability and fish population such as would enhance local fisheries. Previously, for the AR fish assemblage, the rapid increase of macrobenthic community production in the months shortly after the Faro/Ancão AR deployment may have contributed to the fast rate of fish colonisation and stabilization referred to by Leitão et al. (2008) as most of the resident reef fish species are dependent on invertebrates for the purposes of shelter or for food (LEITÃO et al., 2007). While addressing the productivity issue, it is important to examine how epifauna colonising reef habitats enhance the availability of benthic invertebrate prey for the fishery resources (BOHNSACK et al., 1991). Thus, observations on both the horizontal and vertical orientation of the AR surfaces indicate that the initial epibenthic macrofauna colonisation of the horizontal surfaces is higher than it is on the vertical surfaces, which contributes to a substantially increased benthic secondary production. Nevertheless, the results indicate that, after one year, the surface orientation does not seem to affect the production of reef surface area. Our primary objective was to quantify the effect of surface orientation on benthic secondary production. We recognize that secondary production is only one component of ecological benefit, but it is the only ecological metric that at present allows comparisons between habitat types with different species, life histories, and growth rates (BURTON et al., 2002). Other components of ecosystem health, such as biodiversity, were not addressed here (but see Moura et al., 2004; 2008).
Horizontal surface orientation

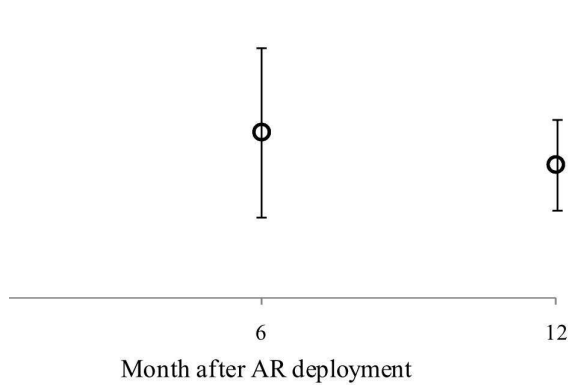

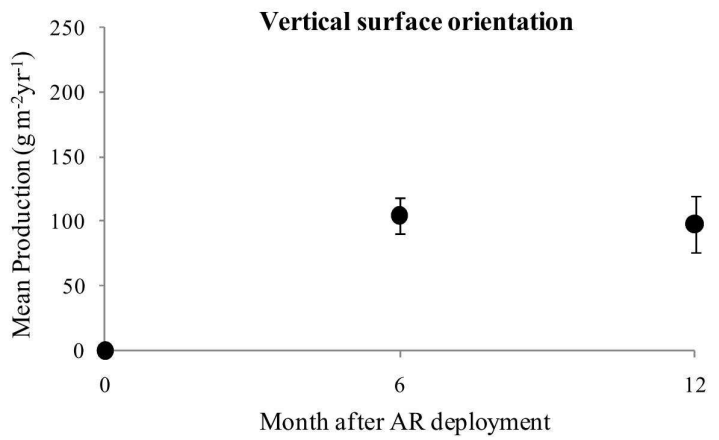

Month after AR deployment

Fig. 1. The production $\left(\mathrm{g} \mathrm{m}^{-2} \mathrm{yr}^{-1}\right)$ estimate for horizontal (left) and vertical (right) surfaces of the Faro/Ancão Artificial Reef system, during the first year after deployment. Vertical bars represent the standard deviations. 
Furthermore, we intended to extrapolate the estimation of secondary production to the whole Algarve AR complex. These systems provide an additional surface area of almost $50000 \mathrm{~m}^{2}$ for the development of encrusting communities (thus increasing species richness) and shelter that attracts different fish species: the attraction-production controversy (SVANE; PETERSEN, 2001). After the first year of colonisation, A. Moura (unpublished data) reported that, for the Faro/Ancão ARs, biomass had been declining throughout the study of four years of colonisation. It is thus also possible that secondary production could have been diminishing throughout that period. Moreover, Moura et al. (2006) observed that biomass production was affected by depth and reef layer. It can, nevertheless, be argued that variability in the productivity of different taxa, associated with age structure and environmental factors, may be large. ARs apparently may enhance benthic secondary production per unit area on the southern coast of the Algarve, but further studies over a longer period of time are called for.

\section{ACKNOWLEDGEMENTS}

We thank the IPIMAR scientific diving team (Francisco Leitão and João Cúrdia) and the crew of RV TELLINA for helping in the fieldwork. We are grateful to João Cúrdia, Susana Carvalho, Marco Cerqueira, Ana Barradas, Francisco Leitão, Rita Constantino, Mafalda Ferreira and Carlos Campos for their help during sampling processing and species identification. This study was carried out within the project "Implantação e estudo integrado de sistemas recifais," supported by the MARE program.

\section{REFERENCES}

BAINE M. Artificial reefs: a review of their design, application, management and performance. Ocean Coast. Mgmt, v. 44, p. 241-259, 2001.

BOHNSACK, J. A.; SUTHERLAND, D. L. Artificial reef research: A review with recommendations for future priorities. Bull. mar. Sci., v. 37, p. 11-39, 1985.

BOHNSACK, J. A.; JOHNSON, D. L.; AMBROSE, R. F. Ecology of artificial reef habitats and fishes. In: SEAMAN JR., W.; SPRAGUE, L. (Ed.). Artificial habitats for marine and freshwater fisheries. London: Academic Press, p. 61-107, 1991.

BREY, T. Population dynamics in benthic invertebrates: A virtual handbook. V.01.2. Alfred Wegener Institute for Polar and Marine Research, Germany, 2002. http://www.thomasbrey.de/science/virtualhandbook/index.html.

BURTON, W. H.; FARRAR, J. S.; STEIMLE, F.; CONLIN, B. Assessment of out-of-kind mitigation success of an artificial reef deployed in Delaware Bay, USA. ICES J. mar. Sci., v. 59, p. S106-S110, 2002.
JOHNSON, T. D.; BARNETT, A. M.; DEMARTINI, E. E.; CRAFT, L. L.; AMBROSE, R. F.; PURCELL, L. J. Fish production and habitat utilization on a southern California artificial reef. Bull. Mar. Sci., v. 55, p. 709723, 1994.

LEITÃO, F. SANTOS, M. N.; MONTEIRO, C. C. Contribution of artificial reefs to the diet of the white sea bream (Diplodus sargus). ICES J. Mar. Sci.,v. 64, p. 473-478, 2007.

LEITÃO, F.; SANTOS, M. N.; ERZINI, K.; MONTEIRO, C.C. Fish assemblages and rapid colonisation after enlargement of an artificial reef off the Algarve coast (Southern Portugal). Mar. Ecol., v. 29, p. 435-448, 2008.

MORIN, A.; MOUSSEAU, T. A.; ROFF, D. A. Accuracy and precision of secondary production estimates. Limnol. Oceanogr., v. 32: 1342-1352, 1987.

MOURA, A.; BOAVENTURA, D.; CÚRDIA, J.; CARVALHO, S.; PEREIRA, P.; CANCELA da FONSECA, L.; LEITÃO, F.; SANTOS, M.N.; MONTEIRO, C. C. Benthic succession on an artificial reef in the south of Portugal - Preliminary results. Rev. Biol., v. 22: 169-181, 2004.

MOURA, A.; BOAVENTURA, D.; CÚRDIA, J.; SANTOS, M. N.; MONTEIRO, C. C. Biomass production of early macrobenthic communities at the Faro/Ancão artificial reef (Portugal): effect of depth and reef layer. Bull. Mar. Sci., v. 78, p. 83-92, 2006.

MOURA, A.; CANCELA DA FONSECA, L.; CÚRDIA, J.; CARVALHO, S.; BOAVENTURA, D.; CERQUEIRA, M.; LEITÃO, F.; SANTOS, M.N.; MONTEIRO, C.C. Is surface orientation a determinant for colonisation patterns of vagile and sessile macrobenthos on artificial reefs? Biofouling, v. 24, p. 381-391, 2008.

SVANE, I.; PETERSEN, J. K. On the problems of epibioses, fouling and artificial reefs: a review. Mar. Ecol., v. 22: 169-188, 2001.

WILSON, J.; OSENBERG, C. W.; ST. MARY, C. M.; WATSON, C. A.; LINDBERG, W. J. Artificial Reefs, the attraction-production issue, and density dependence in marine ornamental fishes. Aquarium Sci. Conserv., v. 3, p. 95-105, 2001.

YABLONSKAYA, E. A.; BEKMAN, M. Y.; WINDBERG, G.G. Methods for the estimating the production of populations without continuous recruitment. In: WINDBERG, G.G. (Ed.). Methods for the estimates of production of aquatic animals. London: Academic Press. 65-94, 1971.

(Manuscript received 21 May 2010; revised 04 April 2011; accepted 11 April 2011) 